\title{
8. STABLE ISOTOPE RATIOS (OXYGEN, HYDROGEN) AND PETROLOGY OF HYDROTHERMALLY ALTERED DOLERITES AT THE BOTTOM OF THE SHEETED DIKE COMPLEX OF HOLE 504B ${ }^{1}$
}

\author{
Pierre Agrinier, ${ }^{2}$ Christine Laverne, ${ }^{3}$ and Paola Tartarotti ${ }^{4}$
}

\begin{abstract}
Dolerite samples, recovered in the dike complex between 1589 and 1991 meters below seafloor in Hole 504B during Legs 137/140, have been altered by hydrothermal fluids as shown by the intense replacement of igneous minerals by secondary amphiboles, chlorites, albite, and anorthite. These rocks display a negative correlation between alteration extent and density. This is interpreted in terms of the development of secondary light minerals and an increase in porosity.

For hydrogen, secondary hydroxyl groups (amphibole) dominate over igneous volatiles and control the $\delta \mathrm{D}_{\text {whole-rock }}$ (-53\%o to $-40 \%$ mean $=-44 \%$ ), the $\mathrm{D} / \mathrm{H}$ fractionation between amphibole (actinolite) and water being about $-44 \% \pm \pm 3 \%$ at $350^{\circ} \mathrm{C}$ assuming the fluid has a seawater $\mathrm{D} / \mathrm{H}$ ratio $\left(\delta \mathrm{D}_{\text {fluid }}=0 \%\right)$.

The $\delta^{18} \mathrm{O}_{\text {whole-rock }}$ values, ranging from $4.7 \%$ to $2.7 \%$ (mean $=4.1 \%$ ), are negatively correlated with the abundance of secondary amphiboles, chlorites, and albite (alteration percent) determined by point counting. The comparison of halos related to veins or patches with less altered adjacent parts shows that the process of alteration produces an increase in the amphibole content related to a decrease in the $\delta^{18} \mathrm{O}_{\text {halo/patch. }}$ The halos/patches from the deepest samples in Hole 504B have the lowest $\delta^{18} \mathrm{O}_{\text {whole-rock }}$ values. This feature can be explained by the progressively decreasing proportion of albite with depth in the dike section. According to Taylor's model, the depletion in ${ }^{18} \mathrm{O}$ of these dolerites (relative to fresh magmatic values: $\delta^{18} \mathrm{O}_{\text {whole-rock }} \approx 5.7 \%$ ) is explained by seawater-rock interaction in which the seawater/rock ratio is higher than 0.15 in atomic proportion $(\approx 0.3$ in mass). Consequently, we deduce that large quantities of seawater-derived fluids have circulated deep in the lower part of the sheeted dike complex of Hole 504B.

The $\delta^{18} \mathrm{O}$ profile in Hole 504B shows a net disequilibrium in the ${ }^{18} \mathrm{O}$ exchange between seawater and the oceanic crust in favor of enrichment in ${ }^{18} \mathrm{O}$ in the seawater. This can be explained by a particular strong expression of high-temperature hydrothermal interaction with seawater-derived fluids at shallow depths (i.e., in Layer 2).
\end{abstract}

\section{INTRODUCTION}

During Legs 137/140, Deep Sea Drilling Project/Ocean Drilling Program Hole 504B was extended by $379 \mathrm{~m}$ into the oceanic crust sheeted dike complex to a total depth of 2000.4 meters below seafloor (mbsf) (Dick, Erzinger, Stokking, et al., 1992). By analogy with ophiolite complexes and other oceanic sites (Nicolas, 1991; Francheteau et al., 1992), Hole 504B is probably near the oceanic crust Layer 2 to 3 transition, providing the opportunity to study the base of Layer 2. This paper describes the alteration features of the rocks, through a coupled stable isotope and petrological study of secondary assemblages, to constrain the conditions (water/rock ratio, temperature) under which fluids penetrated and reacted to form secondary minerals. This should aid the understanding of the mechanisms of exchange of chemical elements between seawater and the oceanic crust.

Pioneer work on seafloor basalts altered at low temperature has shown the interest of such coupling (Muehlenbachs and Clayton, 1972; Javoy and Fouillac, 1979; Böhlke et al., 1981, 1984). Previous oxygen isotope studies (Barrett and Friedrichsen, 1982; Friedrichsen, 1985; Alt et al., 1985, 1986, 1989; Kawahata et al., 1987; Kusakabe et al., 1989) of samples recovered higher in Hole 504B have suggested a progressive decrease of the whole-rock $\delta^{18} \mathrm{O}$ with depth. This feature is explained by exchange of oxygen isotopes between rocks and seawater-derived fluids under progressively higher temperature conditions (ranging from about $100^{\circ} \mathrm{C}$ at the top to about $350^{\circ} \mathrm{C}$ at the bottom; Alt et al., 1989; Kusakabe et al., 1989). Hydrogen whole-rock

\footnotetext{
'Erzinger, J., Becker, K., Dick, H.J.B., and Stokking, L.B. (Eds.), 1995, Proc, ODP, Sci. Results, 137/140: College Station, TX (Ocean Drilling Program).

${ }^{2}$ Laboratoire de Géochimie des Isotopes Stables, Institut de Physique du Globe de Paris, 2 Place Jussieu, 75251 Paris Cedex 05, France.

${ }^{3}$ Laboratoire de Pétrologie Magmatique, Université Aix-Marseille III. URA CNRS 1277, Faculté St. Jérôme, 13397 Marseille Cedex 20, France.

${ }^{4}$ Dipartimento di Geologia, Via Giotto 1.35137 Padova, Italy.
}

values (Friedrichsen, 1985; Kawahata et al., 1987; and Kusakabe et al., 1989) display an increase with depth in $\delta \mathrm{D}$ values $(-60 \%$ to $-30 \%$ ) from 0 to $1000 \mathrm{mbsf}$ and then a decrease in $\delta \mathrm{D}$ values $(-30$ to -45 ) below (1000 to $1500 \mathrm{mbsf})$. These results are in good agreement with petro-mineralogical studies that describe formation of lowtemperature minerals (celadonite, smectite, oxyhydroxides, $\mathrm{Na}-\mathrm{Ca}$ zeolites, etc.) in the upper part of the hole (extrusive complex) and higher-temperature minerals (chlorite, talc, actinolite, titanite, albite, epidote, etc.) in the lower parts: the sheeted dike complex (Honnorez et al., 1983; Alt et al., 1985, 1986; Laverne et al., 1989).

\section{SAMPLES AND ALTERATION FEATURES}

Samples were collected as solid blocks or as powder prepared for on-board whole-rock X-ray fluorescence (XRF) chemical analysis. In both cases, a brief summary of their main petrographic features is given in Table 1; more details are available either in Laverne et al. (this volume); Tartarotti et al., (this volume), or in the Leg 140 Initial Reports volume (Dick, Erzinger, Stokking, et al., 1992). Particular attention was given to the comparison between the oxygen isotopic characteristics of the alteration halos adjacent to veins and patches (where alteration is more pronounced) and that of the surrounding "fresh" rocks. A brief summary of the alteration features of the section cored during Legs $137 / 140$ is given below:

Fresh, unaltered dolerite mainly contains plagioclase $\left(\mathrm{An}_{60-75}\right)+$ augite + titanomagnetite + olivine $\left(\mathrm{Fo}_{86-88}\right)+$ spinel, and has a tholeiitic bulk composition. The dolerite is generally primitive, with $\mathrm{Mg}$ * around 65 .

All dolerite samples are affected by a pervasive background alteration, characterized by $5 \%-40 \%$ replacement of primary minerals by secondary phases.

In addition to the pervasive background alteration, many dolerite samples contain alteration patches and actinolite, chlorite, and chlorite + actinolite veins with or without adjacent alteration halos. The patches 
Table 1. Results of isotopic analyses.

\begin{tabular}{|c|c|c|c|c|c|c|c|c|c|c|c|c|}
\hline $\begin{array}{l}\text { Core, section, } \\
\text { interval }(\mathrm{cm})\end{array}$ & Piece \# & Type & $\begin{array}{l}\text { Depth } \\
\text { (mbsf) }\end{array}$ & $\delta \mathrm{D}$ & $\mathrm{H}_{2} \mathrm{O}^{+}$ & $\delta^{18} \mathrm{O}$ & Density & $\begin{array}{l}\text { Alt } \\
(\%)\end{array}$ & $\begin{array}{l}\mathrm{Ab} \\
(\%)\end{array}$ & $\begin{array}{c}\text { Amp } \\
(\%)\end{array}$ & $\begin{array}{l}\text { Chl } \\
(\%)\end{array}$ & Miscellaneous \\
\hline \multicolumn{13}{|l|}{ 137-504B- } \\
\hline 175R-1, 19-21 & $3 \mathrm{~B}$ & XRF & $1589.9 \pm 0.7$ & -49 & 0.98 & 4.28 & $2.999^{*}$ & 37 & 6 & 25 & 6 & \\
\hline $181 \mathrm{M}-1,7-9$ & 1 & XRF & $1620.5 \pm 0.1$ & -42 & 0.97 & 4.64 & & & & & & \\
\hline \multicolumn{13}{|l|}{ 140-504B- } \\
\hline 185R-1, 15-19 & 3 & XRF & $1624.5 \pm 0.9$ & -44 & 1.17 & 4.23 & & 31 & 2.4 & 23.8 & 5 & \\
\hline $186 \mathrm{R}-1,135-137$ & $17 \mathrm{~A}$ & XRF & $1629.5 \pm 0.3$ & -46 & 1.94 & 3.79 & & 50 & & & & \\
\hline $187 \mathrm{R}-1,5-9$ & 2 & XRF & $1633.3 \pm 0.8$ & -49 & 1.4 & 4.48 & & 1 & 0 & 0 & 0 & \\
\hline $188 \mathrm{R}-1,21-23$ & $7 \mathrm{~A}$ & XRF & $1646.6 \pm 1.2$ & -40 & 1.5 & 3.99 & & 30 & 6 & 21.8 & 2 & \\
\hline $189 R-2,76-79$ & 10 & "FP" & $1654.3 \pm 0.1$ & & & 4.19 & & & 0 & 0 & & \\
\hline 189R-2, 76-79 & 10 & "INT HALO" & $1654.3 \pm 0.1$ & & & 3.25 & & & 8 & 55 & & \\
\hline 189R-2, 76-79 & 10 & "EXT HALO" & $1654.3 \pm 0.1$ & & & 4.15 & & & 18 & 60 & & \\
\hline $189 \mathrm{R}-2,83-86$ & 12 & XRF & $1654.4 \pm 0.1$ & & & 4.37 & & 26 & 4.2 & 15 & 7.2 & \\
\hline $191 R-1,6-11$ & 2 & "FP" & $1662.1 \pm 0.5$ & & & 4.08 & $2.941 \pm 0.015$ & & 0 & 5 & & \\
\hline $191 \mathrm{R}-1,6-11$ & 2 & "HALO" & $1662.1 \pm 0.5$ & & & 4.68 & $2.823 \pm 0.042$ & & 20 & 44 & & \\
\hline $193 R-1,28-31$ & 9 & XRF & $1678.0 \pm 0.7$ & -43 & 2.68 & 4.23 & & 43 & 13 & 23.8 & 6.4 & \\
\hline $194 \mathrm{R}-1,84-87$ & 16 & "FP" & $1686.6 \pm 0.8$ & & & 4.4 & $2.906 \pm 0.011$ & & 4 & 20 & & \\
\hline 194R-1, 84-87 & 16 & "PATCH" & $1686.6 \pm 0.8$ & & & 4.42 & $2.812 \pm 0.009$ & & 15 & 40 & & \\
\hline $194 \mathrm{R}-1,120-123$ & 23 & "FP" & $1689.2 \pm 0.3$ & & & 4.29 & $2.937 \pm 0.016$ & & 4 & 0 & & \\
\hline $194 \mathrm{R}-1,120-123$ & 23 & "HALO" & $1689.2 \pm 0.3$ & & & 4.32 & $2.731 \pm 0.048$ & & 12 & 44 & & \\
\hline 196R-1, 39-42 & 9 & XRF & $1702.1 \pm 0.6$ & & & 4.12 & & 22 & 1.8 & 16.2 & 4.4 & \\
\hline $198 \mathrm{R}-1,56-60$ & 15 & WR & $1717.1 \pm 0.6$ & & & 4,43 & & & & & & Olivine relicts \\
\hline $199 \mathrm{R}-1,14-16$ & 4 & WR & $1720.5 \pm 0.4$ & & & 4.31 & & & & & & Olivine relicts \\
\hline $199 \mathrm{R}-2,6-10$ & 1B & WR & $1728.3 \pm 0.2$ & & & 4.24 & & & & & & Olivine relicts \\
\hline $200 R-1,62-66$ & 13 & WR & $1730.0 \pm 0.2$ & & & 4.39 & & & & & & Olivine relicts \\
\hline 200R-2, 11-14 & 14 & WR & $1733.4 \pm 0.3$ & & & 4.42 & & & & & & \\
\hline $200 R-3,59-63$ & $8 \mathrm{~B}$ & XRF & $1735.3 \pm 0.3$ & & & 4.35 & & & & & & \\
\hline $200 R-4,42-45$ & 11 & "FP" & $1737.4 \pm 0.1$ & & & 4.7 & $2.925 \pm 0.029$ & & 0 & 2 & & \\
\hline $200 R-4,42-45$ & 11 & "HALO" & $1737.4 \pm 0.1$ & & & 4.07 & $2.906 \pm 0.061$ & & 5 & 46 & & \\
\hline 201R-1, 19-23 & 5 & XRF & $1745.6 \pm 1.3$ & & & 3.6 & & 19 & 0.8 & 17.6 & 0.6 & \\
\hline $202 R-1,41-45$ & 11 & XRF & $1748.4 \pm 0.2$ & -41 & 1.7 & 4.03 & & 16 & 2 & 7.2 & 6.8 & \\
\hline $203 R-1,39-42$ & 12 & XRF & $1754.5 \pm 0.7$ & -44 & 1.81 & 3.28 & & 42 & 6.4 & 34.8 & 1 & \\
\hline $204 \mathrm{R}-1,28-32$ & 7 & XRF & $1756.8 \pm 0.1$ & -53 & 1.82 & 3.39 & & 37 & 10.6 & 25.4 & 1.4 & \\
\hline $205 \mathrm{R}-1,10-13$ & 1 & XRF & $1757.1 \pm 0.1$ & -40 & 1.79 & 2.76 & & 72 & 24 & 47.2 & 0.6 & \\
\hline 207R-1, 0-4 & 1 & XRF & $1768.9 \pm 0.5$ & -47 & 1.02 & 3.57 & & 21 & 1.6 & 19 & 0 & \\
\hline $208 \mathrm{R}-1,0-3$ & 1 & XRF & $1778.1 \pm 0.1$ & & & 4.5 & & 9 & 0 & 4.2 & 0.4 & \\
\hline $208 \mathrm{R}-1,18-21$ & 4 & WR & $1778.7 \pm 0.3$ & & & 4.29 & & & & & & Olivine relicts \\
\hline $208 \mathrm{R}-1,56-61$ & 14 & "FP" & $1780.4 \pm 0.4$ & & & 4.69 & $2.977 \pm 0.011$ & & 0 & 2 & & \\
\hline $208 \mathrm{R}-1,56-61$ & 14 & "HALO" & $1780.4 \pm 0.4$ & & & 3.77 & $2.897 \pm 0.035$ & & 2 & 48 & & \\
\hline $208 \mathrm{R}-2,76-81$ & 13 & WR & $1785.6 \pm 0.4$ & & & 4.05 & & & & & & \\
\hline $208 \mathrm{R}-3,7-10$ & 1 & XRF & $1787.3 \pm 0.1$ & -50 & 2.48 & 4.11 & & 75 & 8.4 & 60.4 & 6 & \\
\hline 209R-1, 66-69 & 11 & "FP" & $1789.4 \pm 0.3$ & & & 4.24 & $2.896 \pm 0.020$ & & 0 & 5 & & \\
\hline 209R-1, 66-69 & 11 & "HALO" & $1789.4 \pm 0.3$ & & & 3.52 & $2.767 \pm 0.032$ & & 5 & 49 & & \\
\hline 209R-2, 108-111 & 17B & "FP" & $1793.3 \pm 0.3$ & & & 4.21 & $2.970 \pm 0.026$ & & & 0 & & \\
\hline 209R-2, 108-111 & 17B & "PATCH" & $1793.3 \pm 0.3$ & & & 4.13 & $2.937 \pm 0.007$ & & & 50 & & \\
\hline $211 R-1,136-140$ & $30 \mathrm{~B}$ & XRF & $1805.8 \pm 0.2$ & -46 & 1.1 & 4.33 & & & & & & \\
\hline $212 \mathrm{R}-1,4-7$ & 1B & XRF & $1806.3 \pm 0.3$ & -47 & 1.14 & 4.4 & $3.001^{*}$ & 18 & 0.4 & 15.6 & 2 & \\
\hline $212 \mathrm{R}-1,61-65$ & 17 & "FP" & $1812.1 \pm 0.3$ & & & 4.38 & $2.993 \pm 0.020$ & & 0 & 4 & & \\
\hline $212 R-1,61-65$ & 17 & "HALO" & $1812.1 \pm 0.3$ & & & 4.15 & $3.076 \pm 0.082$ & & 0 & 50 & & \\
\hline $213 \mathrm{R}-1,79-83$ & 21 & XRF & $1816.1 \pm 0.4$ & -45 & 0.91 & 4.71 & & 0 & 0 & 0 & 0 & \\
\hline $214 \mathrm{R}-1,24-28$ & $5 A$ & XRF & $1819.0 \pm 0.1$ & -44 & 2.19 & 3.68 & & 82 & 10.6 & 70.4 & 1.4 & \\
\hline $214 R-2,0-5$ & 1 & WR & $1821.0 \pm 0.2$ & & & 3.74 & & & 6 & 49 & & \\
\hline $214 \mathrm{R}-2,29-32$ & 7 & XRF & $1821.6 \pm 0.2$ & -41 & 1.77 & 3.8 & & 44 & 4.2 & 38 & 1.6 & \\
\hline $214 \mathrm{R}-2,100-103$ & 22 & XRF & $1822.6 \pm 0.1$ & -40 & 1.55 & 4.13 & & 12 & 0 & 6.4 & 6 & \\
\hline $215 \mathrm{R}-1,0-4$ & 1 & XRF & $1823.2 \pm 0.2$ & -42 & 1.38 & 4.08 & $2.998^{*}$ & 14 & 0.2 & 10.8 & 4.4 & \\
\hline $215 R-1,43-46$ & 12 & WR & $1825.7 \pm 0.5$ & & & 4.08 & & & & & & \\
\hline $216 \mathrm{R}-1,66-68$ & 14 & XRF & $1834.9 \pm 0.9$ & -40 & 1.57 & 3.94 & & 7 & 0.8 & 0.8 & 5.4 & \\
\hline $217 \mathrm{R}-1,23-26$ & 6 & XRF & $1845.5 \pm 1.1$ & & & 4.38 & & 7 & 0 & 0.4 & 6.6 & \\
\hline $220 \mathrm{R}-1,27-30$ & 7 & $\mathrm{XRF}$ & $1873.8 \pm 1.0$ & -41 & 1.95 & 3.79 & $3.006^{*}$ & 16 & 3 & 6.4 & 6.4 & \\
\hline 222R-1, 101-104 & 19 & XRF & $1891.7 \pm 0.7$ & & & 3.72 & $2.969 *$ & 35 & 4.2 & 26 & 4.6 & \\
\hline $224 \mathrm{R}-1,59-62$ & 14 & $\mathrm{XRF}$ & $1909.7 \pm 0.8$ & -44 & 1.28 & 3.5 & $2.995^{*}$ & 37 & 0.4 & 37 & 0 & \\
\hline $225 \mathrm{R}-1,126-129$ & 33 & "FP" & $1916.5 \pm 0.4$ & & & 4.37 & $2.991 \pm 0.015$ & & 0 & 0 & & \\
\hline $225 \mathrm{R}-1,126-129$ & 33 & "HALO" & $1916.5 \pm 0.4$ & & & 3.57 & $2.898 \pm 0.019$ & & 0 & 42 & & \\
\hline $226 \mathrm{R}-1,16-20$ & 3 & XRF & $1920.2 \pm 0.1$ & -42 & 1.14 & 4.19 & & 18 & 0 & 15 & 2.8 & \\
\hline $227 R-2,0-5$ & 1 & XRF & $1924.8 \pm 0.3$ & -44 & 1.7 & 4.06 & & 23 & 0.8 & 12.2 & 8.4 & \\
\hline $236 \mathrm{R}-1,57-60$ & 8 & WR & $1982.4 \pm 0.3$ & & & 3.57 & & & 1 & 40 & & \\
\hline $237 \mathrm{R}-1,24-26$ & 7 & WR & $1991.0 \pm 0.9$ & & & 4.09 & & & & & & \\
\hline $504 \mathrm{~B}$ BAS $/ 4-4$ & & REFERENCE & & -44 & 0.97 & 4.34 & & & & & & \\
\hline
\end{tabular}

Notes: Depths have been evaluated according to the probabilistic model developed by Agrinier and Agrinier (in press). In the Type column: WR = solid sample from vein-free sample, $\mathrm{XRF}=$ powder prepared for X-ray fluorescence analysis on the ship, "HALO" = alteration halo adjacent to vein, "FP" = corresponding fresher rock adjacent to alteration halo, "PATCH" = patch of alteration, and REFERENCE = standard for laboratory comparison. Alt = the percent alteration determined by point counting, $\mathrm{Ab}=$ the percent albite, Amp = the percent amphibole, and $\mathrm{Chl}=$ the percent chlorite + mixed-layer smectite-chlorite. Samples with olivine relicts are quoted in the miscellaneous column. In the Density column, * refers to shipboard measured density, data from table 22 of Dick, Erzinger, Stokking, et al. (1992).

are irregularly shaped regions, usually up to several centimeters across, of highly altered (up to $100 \%$ ) dolerite, where hydrothermal solutions had increased access to the dolerite. Alteration halos adjacent to veins are usually characterized by extensive recrystallization (typically $40 \%-$ $90 \%$ ). Samples are heterogeneous in their alteration features, both in the relative abundances and in the chemical composition of the various secondary minerals (Laverne et al., Tartarotti et al., this volume).
In both the alteration halo and the fresher host-rock, clinopyroxene is mainly replaced by various amphiboles (actinolite, act-hornblende, ferro-actinolite, and Mg-hornblende) and sometimes by chlorite. Olivine is variably replaced by chlorite, mixed-layer chlorite-smectite, talc, and talc-chlorite, quartz, sulfides, magnetite, and hematite. Plagioclase in the alteration halos may be replaced by one or two generations of secondary plagioclase (anorthite and albite), minor anhydrite, laumon- 
tite, epidote, chlorite, actinolite, or some combination of these minerals, whereas plagioclase is almost completely fresh outside the halos. Titanomagnetite is replaced by titanite in the alteration halos and patches.

Hydrothermal veins, about $1 \mathrm{~mm}$ wide, generally consist of actinolite, chlorite, or actinolite and chlorite.

Although the extent of alteration is irregular downhole, there is a general trend toward an increasing proportion of amphibole and secondary anorthite and a decreasing proportion of albite with depth in the dike section. Of particular interest is the occurrence of fresh olivine relicts from 1705 to $1733 \mathrm{mbsf}$ and more sporadically at still greater depth in the hole, whereas no fresh olivine occurs in the upper dike section.

According to Laverne et al. (this volume), the hydrothermal features of these dolerites can be described by a five-stage history. Initially, minor secondary clinopyroxene + Ca-plagioclase (mainly anorthite) + hornblende assemblage form locally in some halos at temperature around $500^{\circ} \mathrm{C}$. Then, the main alteration occurs at a lower temperature $\left(\approx 350^{\circ} \mathrm{C}\right)$ where actinolite + chlorite + albite assemblage form ubiquitously. This alteration is much more pronounced in the halos. Later, minor quartz + epidote form locally in some veins and halos. During the two minor last stages, anhydrite and then zeolites + prehnites form locally in veins and halos.

\section{ANALYTICAL PROCEDURE AND NOTATION}

The density of samples was measured in solid blocks with a picnometer assuming that density of water is $0.9957( \pm 0.0002)$ at $25^{\circ} \mathrm{C}$. For small blocks, the precision of the density measurement greatly depends on the mass of the sample. Except for the halo of Sample 140-504B-212R-1, 126-129 cm, the precision is better than $\pm 0.05 \mathrm{~g} / \mathrm{cm}^{3}$.

Oxygen was extracted from silicates by bromine pentafluoride at $550^{\circ} \mathrm{C}$ (Clayton and Mayeda, 1963) and reacted with carbon to give $\mathrm{CO}_{2}$. Hydrogen was either directly extracted as $\mathrm{H}_{2}$ by heating a rock + zinc mixture at $950^{\circ} \mathrm{C}$, for $10 \mathrm{~min}$, in a sealed quartz tube (Agrinier and Javoy, unpubl. data) or extracted as water, by fusion of the sample, and subsequently reacted with zinc at $450^{\circ} \mathrm{C}$ to give $\mathrm{H}_{2}$ (Coleman et al., 1982). Adsorbed water was removed by outgassing the samples for $2 \mathrm{hrs}$ at $120^{\circ} \mathrm{C}$ under vacuum. Both methods were found to give $\delta \mathrm{D}$ values in agreement better than $\pm 2 \%$. The hydrogen yield was then measured manometrically for determination of water contents $\left[\mathrm{H}_{2} \mathrm{O}^{+}\right]$wt\%.

$\mathrm{CO}_{2}$ and $\mathrm{H}_{2}$ were then analyzed on a mass spectrometer to determine the ${ }^{18} \mathrm{O} /{ }^{16} \mathrm{O}$ and $\mathrm{D} / \mathrm{H}$ ratios. The isotopic composition of a sample is given as $d_{\text {sample }}=\left(R_{\text {sample }} / R_{\text {standard }}-1\right) \cdot 1000$ in per mil unit $(\%)$, where $\mathrm{R}$ is ${ }^{18} \mathrm{O} /{ }^{16} \mathrm{O}$ or $\mathrm{D} / \mathrm{H}$ and the standard being SMOW for oxygen and hydrogen. Analytical errors for oxygen and hydrogen isotope ratios are better than $0.2 \%$ and $3 \%$, respectively. Analytical errors (s) for water content are better than $0.1 \mathrm{wt} \%$. During the spring and summer of 1992 , the $\delta^{18} \mathrm{O}$ mean value of NBS28 standard was $9.49 \%$ $0.10(n=21)$, the $\delta D$ mean value of NBS30 standard was $-61 \% \pm 3 \%$ $(\mathrm{n}=5)$. The isotopic fractionation factor between two phases $A$ and $B$ is defined as $\Delta(A-B)=\delta A-\delta B$.

\section{RESULTS}

The nature (type, percent alteration, percent albite, percent amphibole, and percent chlorite + mixed-layer chlorite-smectite), $\delta \mathrm{D}_{\text {whole-rock }}$, water content $\left[\mathrm{H}_{2} \mathrm{O}^{+}\right], \delta^{18} \mathrm{O}_{\text {whole-rock }}$, and density of the samples are presented in Table 1 . The percent alteration, percent albite, percent actinolite, and percent chlorite + mixed-layer chlorite-smectite were estimated, based on the abundance of grains $\geq 50 \mu \mathrm{m}$ observed and counted in $2 \times 2 \mathrm{~cm}^{2}$ thin section. As estimates, percent alteration is only a relative index of the true abundance of alteration. An alteration percent value of zero means only that no large grain was found to be altered during the scanning of the thin section. It does not mean that the sample is completely fresh.

\section{Density}

Densities were measured for altered parts (halos or patches) and their adjacent fresher parts for comparison. They range from 3.076 to $2.731 \mathrm{~g} / \mathrm{cm}^{3}($ mean $=2.909 \pm 0.085, \mathrm{n}=20)$. Generally, the altered parts are approximately $0.1 \mathrm{~g} / \mathrm{cm}^{3}$ lighter than the fresh adjacent part, except for Sample 140-504B-212R-1, 61-65 cm. For this sample, this density contrast is not very significant because the density of the altered part is imprecise because the sample was very small (Fig. 1). The observed density contrasts suggest that the alteration processes produce a decrease in density. This change in density can be explained by the replacement of the heavy primary minerals (plagioclase $A n_{70}$ $\left[\rho=2.73 \mathrm{~g} / \mathrm{cm}^{3}\right]$, augite, olivine $\left.\left[\rho \geq 3.2 \mathrm{~g} / \mathrm{cm}^{3}\right]\right)$ by lighter alteration products (albite: $2.63 \mathrm{~g} / \mathrm{cm}^{3}$, chlorite: $2.7-2.9 \mathrm{~g} / \mathrm{cm}^{3}$, amphibole: 3.2 $\left.\mathrm{g} / \mathrm{cm}^{3}\right)$. However, the increase in porosity is also an important factor; it should significantly lower the density of the altered parts. The porosity and the density values measured on board (table 22, p. 133 , Dick, Erzinger, Stokking, et al. [1992]) clearly show that the high porosity samples are also the low-density samples (Fig. 2). This relationship is consistent with alteration processes producing an increase of the porosity of the rock, which should, at least in part, account for the observed decrease of the density.

\section{Water Contents and D/H Ratios}

The water contents ( 0.9 to $2.8 \mathrm{wt} \%$ ) are variable and much higher than in fresh mid-ocean-ridge basalts (MORB) $(\leq 0.5 \%)$, reflecting the importance of hydrous secondary minerals (amphibole, $\left[\mathrm{H}_{2} \mathrm{O}^{+}\right] \approx$ $2 \%$ and chlorite, $\left.\left[\mathrm{H}_{2} \mathrm{O}^{+}\right] \approx 13 \%\right)$. This explains the correlation $(\mathrm{r}=$ $0.635 ; \mathrm{n}=23$ ) between the $\left[\mathrm{H}_{2} \mathrm{O}^{+}\right]$content and the percent alteration estimates (Fig. 3). It is also noted that samples, even with an alteration percent of zero, have water contents $\left(\left[\mathrm{H}_{2} \mathrm{O}^{+}\right] \approx 1 \%\right)$ incompatible with fresh MORB, thus confirming that no dolerites from Leg 140 are fresh, although the percentage of alteration is zero for some samples.

The $\mathrm{D} / \mathrm{H}$ ratios are quite uniform $(-53 \%$ to $-40 \%)$ and higher than in fresh MORB $(-75 \% \pm \pm 15 \%)$, and there is no correlation between the $\delta \mathrm{D}$ and the $\left[\mathrm{H}_{2} \mathrm{O}^{+}\right]$content (Fig. 4). This was expected because the concentration of hydrogen in water $(12.5 \%)$ is about eight times higher than in chlorite and 40 times higher than in amphiboles, and therefore the fluid (seawater-derived) buffers the rock in $\delta \mathrm{D}$ composition (see curve on Fig. 4) with an offset equal to the fractionation factor of the $\mathrm{D} / \mathrm{H}$ ratio between the water and $\mathrm{OH}$-bearing minerals (amphibole and chlorite). Because the main $\mathrm{OH}$-bearing mineral in our rocks is amphibole, the fractionation factor between the rock and water is essentially the one between amphibole and water. If we assume that the $\delta \mathrm{D}$ of the fluid is the one of seawater $(\approx 0 \%)$, we can deduce the value of the fractionation factor between amphibole and water from the following equation:

$\Delta \mathrm{D}$ (actinolite - water $)=\delta \mathrm{D}_{\text {rock }}-\delta \mathrm{D}_{\text {water }} \approx \delta \mathrm{D}_{\text {rock }} \approx-44 \%$ $\pm 3 \%$ (s) .

This value is slightly lower than that determined experimentally for actinolite $\left(-30 \%\right.$ at $400^{\circ} \mathrm{C}$; Graham et al., 1984), but this difference may be explained by both a slightly lower temperature (around $300^{\circ}-350^{\circ} \mathrm{C}$ ) for the actinolite-water reaction and the higher Fe content of our amphiboles $(15.8 \% \pm 3.4[\mathrm{~s}])$ because both factors are known to decrease the $\Delta \mathrm{D}$ (actinolite - water) (Suzuoki and Epstein, 1976). Another possibility would be equilibration with a slightly D-depleted seawater-derived hydrothermal fluid $\left(\delta \mathrm{D}_{\text {water }} \approx-10 \%\right)$, but this seems unlikely because, generally, hydrothermal vent fluids have $\delta D_{\text {water }}$ indistinguishable from that of seawater $\left(\delta D_{\text {seawater }} \approx\right.$ $0 \%-2 \%$; Craig et al., 1980; Merlivat et al., 1987; Bowers and Taylor, 1985). A contribution of hydrogen from chlorite would not significantly change this because chlorite and actinolite have about the same hydrogen fractionation factor with water in this temperature range $\left(350^{\circ}-500^{\circ} \mathrm{C}\right.$; Graham et al., 1987). 


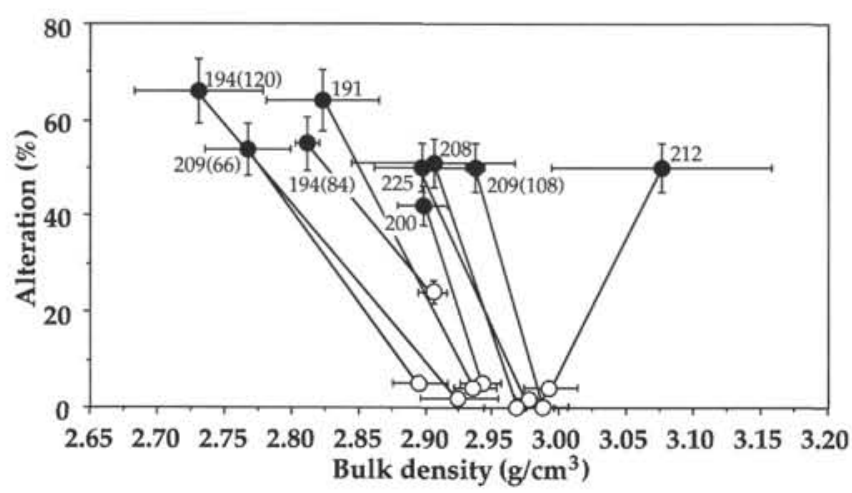

Figure 1. Percentage of alteration vs. density diagram of the altered parts (halos or patches) and adjacent fresher parts (data from Table 1). Lines link the parts from the same samples. Error on the density determination mainly depends upon the size of the block loaded in the picnometer: the smaller the block, the larger the error. The core numbers are given beside the solid circles for sample identification. For Cores 194 and 209 (where two halo-fresh adjacent part pairs have been analyzed), the upper limit in the core is given in parentheses. Solid circles $=$ halos or patches; open circles $=$ fresh adjacent part .

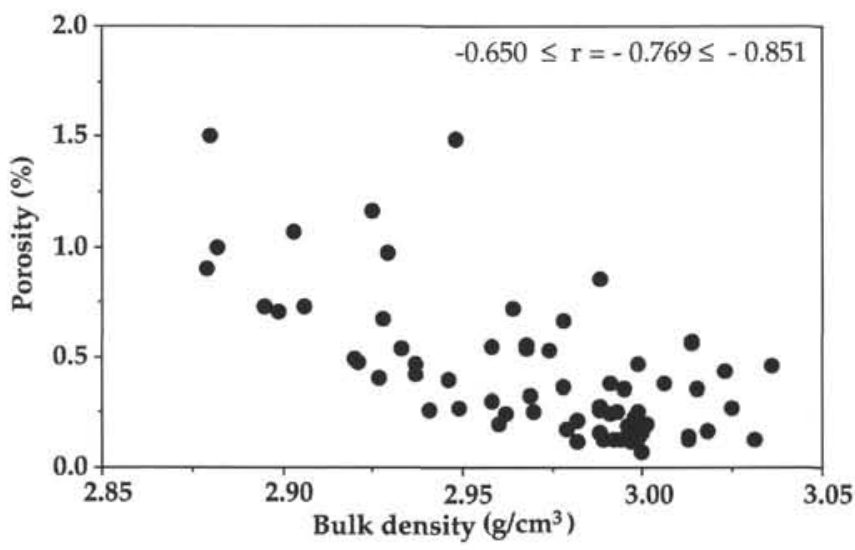

Figure 2. Porosity vs. density diagram for whole-rock samples (data from table 22 of Leg 140 Initial Reports volume). The $95 \%$ confidence interval for the correlation coefficient $(\mathrm{r})$ is given, meaning that we can be $95 \%$ confident that the population correlation coefficient, $\mathrm{r}$, has a value between -0.650 and -0.851 .

\section{Oxygen Isotope Ratios}

The $\delta^{18} \mathrm{O}_{\text {whole-rock }}$ values range between $2.7 \%$ and $4.5 \%$, and no sample, out of 64 samples, has a fresh MORB-like value $\left(\delta^{18} \mathrm{O} \approx\right.$ $5.7 \%$ ). These rocks have been strongly depleted in ${ }^{18} \mathrm{O}$. No correlation has been found with the depth of the sample except a general trend of decreasing $\delta^{18} \mathrm{O}$ with depth for halos and patches (see below and Fig. $6 \mathrm{~A}$ and $6 \mathrm{~B})$. Figure 5 shows that this depletion is correlated $(\mathrm{r}=$ $-0.595, \mathrm{n}=29$ ) with the percent alteration estimates (essentially actinolite, albite, and chlorite, ranked by their occurrence abundances; appendix H of Dick, Erzinger, Stokking, et al. [1992]). This relationship can be explained by the relative content of these secondary minerals. However, the contribution of albite to the ${ }^{18} \mathrm{O}$ depletion in the samples should be less than that of actinolite and chlorite. The reason for that is the difference between oxygen isotope fractionation factors $\Delta$ (amphibole-water), $\Delta$ (chlorite-water $) \approx 0 \%$, which are very low at $350^{\circ} \mathrm{C}$ and $\Delta$ (albite-water) $\approx 5.5 \%$, which is much higher (Bottinga and Javoy, 1975; Wenner and Taylor, 1971; O'Neil and Taylor, 1967). Accordingly, albite that formed during the hydrothermal interaction between oceanic crust rock and seawater (or seawater

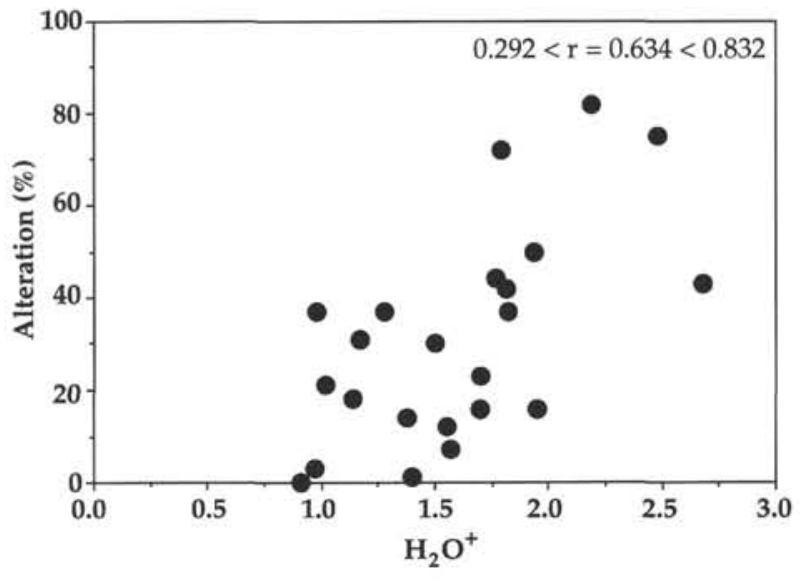

Figure 3. Percent alteration vs. water content wt $\%$ diagram (data from Table 1). The $95 \%$ confidence interval for the correlation coefficient $(r)$ is given.

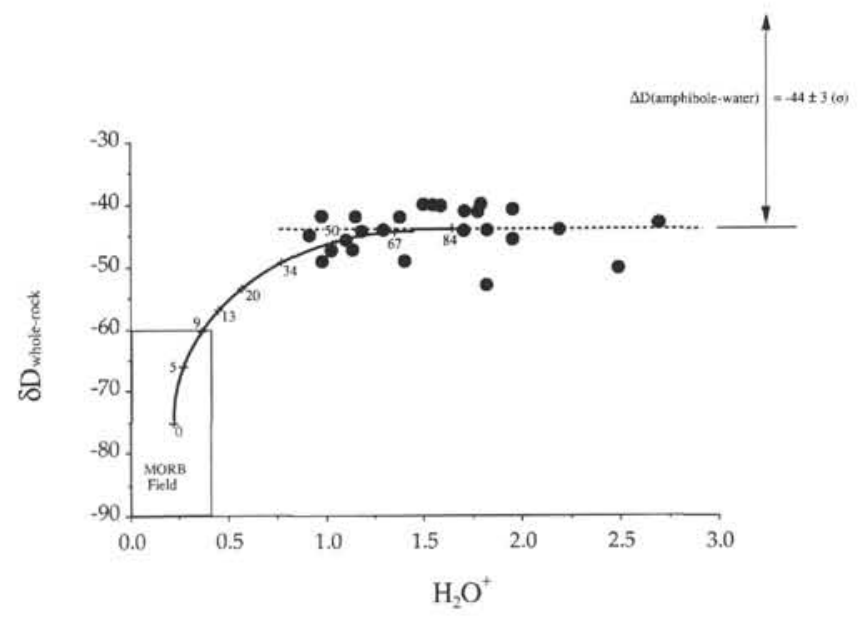

Figure 4. $\delta \mathrm{D}_{\text {whole-rock }}$ vs. water content wt $\%$ diagram (data from Table 1). MORB field is from Kyser and O'Neil (1984) and F. Pineau, N. Jendrzejewski (pers. comm., 1991). The curve is given for the growth of amphibole $\left(\left[\mathrm{H}_{2} \mathrm{O}^{+}\right]\right.$ $\approx 2 \%$ and $\delta \mathrm{D}_{\text {amphibole }}=-44 \%$ ) in a rock with initially $\left[\mathrm{H}_{2} \mathrm{O}^{+}\right]=0.25 \%$ and $\delta \mathrm{D}_{\text {whole-rock }}=-75 \%$ (MORB-like composition). Numbers along the curve are the amphibole amount wt\%. This curve demonstrates that if more than about $2 \%$ in volume of amphibole is produced, the $\delta \mathrm{D}_{\text {whole-rock }}$ is not distinguishable from that of the amphibole $\left(\delta \mathrm{D}_{\text {amphibole }}=-44 \%\right)$. The original signature of igneous hydrogen is masked by that of secondary minerals formed during the hydrothermal interaction.

derived fluid) at $350^{\circ} \mathrm{C}$ should be about $5.5 \%$ richer in ${ }^{18} \mathrm{O}$ than chlorite or amphibole, and as a consequence, would contribute less to the ${ }^{18} \mathrm{O}$ depletion of the whole-rock than would the chlorite or amphibole. The $\delta^{18} \mathrm{O}_{\text {whole-rock }}$ will depend on the respective proportions of actinolite, chlorite (low- $\delta^{18} \mathrm{O}$ minerals) and albite (high- $\delta^{18} \mathrm{O}$ mineral). This is confirmed by the relationship $(r=0.622)$ between the percentage of amphibole and the $\delta^{18} \mathrm{O}_{\text {whole-rock }}$ : the higher the amphibole percent, the lower the $\delta^{18} \mathrm{O}_{\text {whole-rock }}$ (Fig. 6A). Except for the halos and patches where the amphibole percentage is constant $(\approx 50 \%$, Fig. $6 \mathrm{~B}$ ), the albite percentage, highly variable from $0 \%$ to $20 \%$, is positively correlated with the $\delta^{18} \mathrm{O}_{\text {whole-rock }}$ (Fig. 6C) as expected from its calculated high ${ }^{18} \mathrm{O}$ content relative to amphibole or chlorite. Thus it seems that the $\delta^{18} \mathrm{O}_{\text {whole-rock }}$ is mainly (but not completely) controlled by the alteration extent and more specifically by the relative abundance of actinolite + chlorite vs. albite. 


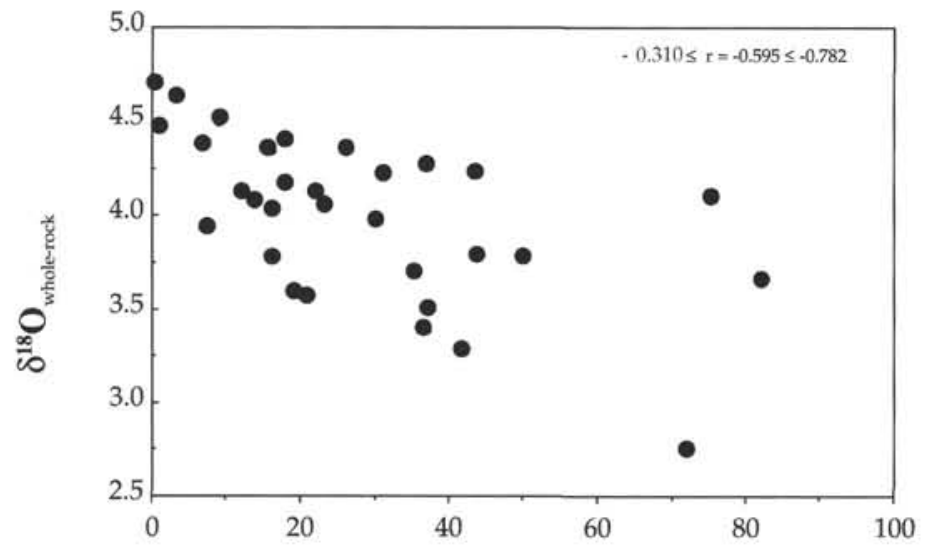

Alteration (\%)

Figure $5 . \delta^{18} \mathrm{O}_{\text {whole-rock }}$ vs. percent alteration diagram (data from Table 1). The $95 \%$ confidence interval for the correlation coefficient $(r)$ is given.

It seems also that in Figure $6 \mathrm{~B}$, the $\delta^{18} \mathrm{O}_{\text {halos }}$ are crudely sorted by their depth: the halos from the deepest samples (those with the higher core number) have the lowest $\delta^{18} \mathrm{O}$ values. The corresponding ranking feature appears on Figure $6 \mathrm{C}$. It can be explained by the progressive decreasing of the proportion of albite with depth in the dike section.

Finally, it is noted that samples that have relicts of olivine (those where olivine is not fully replaced by talc; see Table 1) have high $\delta^{18} \mathrm{O}$ values $(4.35 \pm 0.06 ; n=6)$ compared with the whole range of $\delta^{18} \mathrm{O}(4.09 \pm 0.39 ; \mathrm{n}=64)$. These high $\delta^{18} \mathrm{O}$ values suggest that these olivine-bearing samples are less altered and are in agreement with the preliminary interpretation (Dick, Erzinger, Stokking, et al., 1992; Laverne et al., this volume), which indicates that they were altered under lower water/rock ratio and are relatively less altered than the other samples. These olivine-bearing samples are from low-permeability zones according to the Dual Laterolog Instrument (DLL) resistivity logging data (Harvey et al., this volume).

The oxygen isotope data for the halos/patches and the adjacent fresh parts are presented vs. depth in Figure 7 . We readily see a net contrast between the upper and the lower parts of Hole 504B: above $1700 \mathrm{mbsf}$, the $\delta^{18} \mathrm{O}$ of the halos/patches are higher than the $\delta^{18} \mathrm{O}$ of the adjacent fresh parts, whereas below 1700 mbsf the opposite is true. This feature can be explained by a change in the alteration mineralogy. Alt et al. $(1986,1989)$ shows that the enrichment in ${ }^{18} \mathrm{O}$ of the halos/patches relative to the adjacent fresh part in the upper part is associated with the predominance of high ${ }^{18} \mathrm{O}$ minerals (albite and calcic zeolites) over low ${ }^{18} \mathrm{O}$ minerals (chlorite and actinolite). Meanwhile, in the lower part of Hole 504B, low ${ }^{18} \mathrm{O}$ minerals (actinolite and chlorite) become more abundant, and the albite proportion decreases progressively with depth (see above).

\section{Seawater-Oceanic Crust Hydrothermal Exchange at Bottom of Hole 504B}

As shown above, the Leg 137/140 dolerite samples of Hole 504B have been strongly and quite homogeneously depleted in ${ }^{18} \mathrm{O}$ (the mean depletion is about $1.6 \% \circ \pm 0.4 \%$ relative to the supposed initial value $[\approx 5.7 \%$ of the fresh MORBs), demonstrating the importance of the hydrothermal exchange with seawater-derived fluids because oxygen is the main chemical element of rocks. Of particular interest are estimates of the water/rock ratio (W/R) required to produce such depletions, as it will constrain the extent of mass exchange between seawater and the oceanic crust.

The water/rock ratio can be determined from Taylor's (1977) closed system water-rock interaction model. This model links the change in $\delta^{18} \mathrm{O}$ of a rock (or mineral) due to hydrothermal interaction with three parameters. They describe the conditions of the hydrothermal interaction:
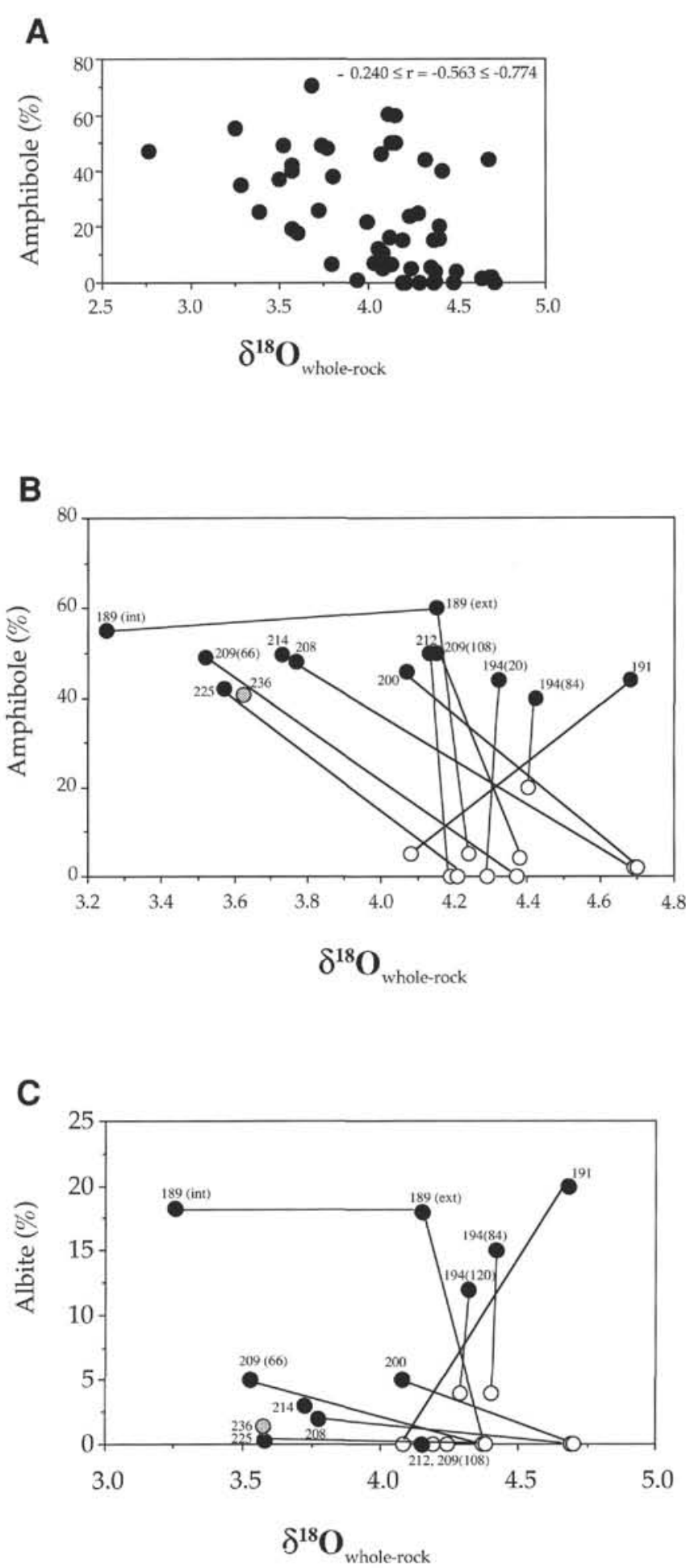

Figure 6. A. Percent amphibole vs. $\delta^{18} \mathrm{O}_{\text {whole-rock }}$ diagram. The $95 \%$ confidence interval for the correlation coefficient $(r)$ is given. B. Percent amphibole vs. $\delta^{18} \mathrm{O}_{\text {whole-rock }}$ diagram of the altered parts (halos or patches) and adjacent fresher parts. The core numbers are given beside the solid circles for sample identification. For Cores 194 and 209 (where two halo-fresh adjacent part pairs have been analyzed), the upper limit in the core is given in parentheses. Line links the halo (or patch) and the adjacent "fresh" part for a given sample. For Sample 140-504B-189R-2, 76-82 cm (Piece 10), an internal halo (int) is contained within an external halo (ext). The internal halo is the walls of the vein. Solid circles $=$ halos and patches; open circles = "fresh adjacent part"; gray circle $=$ whole-rock. C. Percent albite vs. $\delta^{18} \mathrm{O}_{\text {whole-rock }}$ diagram of the altered parts (halos or patches) and adjacent fresher parts. Symbols as in Figure 6B. 


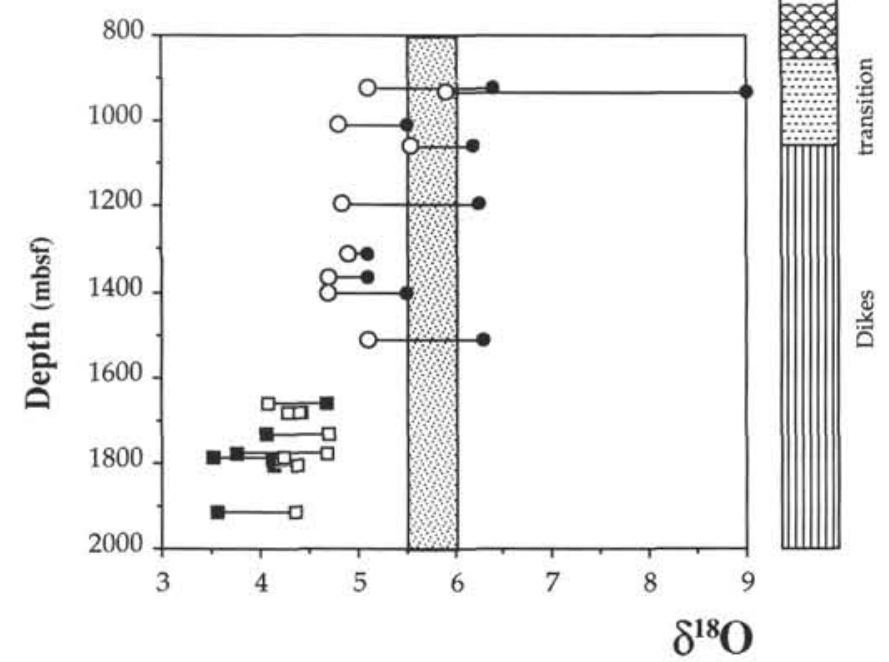

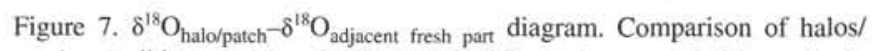
patches (solid symbols) and adjacent "fresh" part (open symbols) vs. depth. Data are from Alt et al. (1986 and 1989; circles) and from this study (squares).

1. The temperature sets the oxygen fractionation factor between rock (or mineral) and water and, as a consequence, sets the direction of the $\delta^{18} \mathrm{O}$ change. The $\delta^{18} \mathrm{O}$ will increase under low-temperature hydrothermal interaction because the fractionation factor is large $(>5.7 \%)$; meanwhile, $\delta^{18} \mathrm{O}$ will decrease at high temperatures because the fractionation factor is small $(<5.7 \%$ o).

2. The water/rock ratio is defined as the ratio of the atom percent oxygen in the water that exchanges with the rock to the atom percent oxygen in the rock that participates in the exchange reaction with the water. The water/rock ratio controls the amount of ${ }^{18} \mathrm{O}$ enrichment or depletion. For a given temperature, the higher the water/rock ratio, the larger the change in $\delta^{18} \mathrm{O}$.

\section{The $\delta^{18} \mathrm{O}$ of the fluid.}

Following this simple model (based upon one single hydrothermal interaction step), we can derive an estimate of the "global" water/rock ratio that can produce the observed ${ }^{18} \mathrm{O}$ depletion if we assume that:

1. The main alteration features were acquired at temperatures of around $350^{\circ} \mathrm{C}$ (Dick, Erzinger, Stokking, et al. (1992); Laverne et al., this volume), although the alteration features of the dolerite samples of Leg 137/140 are the cumulative effects of the hydrothermal interactions over the 6-m.y. period during which the temperature decreased from magmatic temperatures to the present ambient value $\left(\approx 195^{\circ} \mathrm{C}\right)$. Thus, the overall oxygen fractionation factor between the whole-rock and the fluid can be determined from the amphibolewater factor $[\approx \Delta$ (rock-fluid $) \approx 0 \%]$ at temperatures of around $350^{\circ} \mathrm{C}$ according to the theoretical work of Schütze (1984). It should be noted that the problem linked with the uncertainty of the amphibolewater fractionation factor (neither empirical nor experimental calibrations are available for $350^{\circ} \mathrm{C}$ ) is not serious because, for the temperature range of interest, its variations are probably small $(\leq 1 \%$ for $300^{\circ}-400^{\circ} \mathrm{C}$; Schütze, 1984). Therefore, uncertainties on this fractionation will shift the W/R determination toward lower values (if the fractionation factor is overestimated) or toward higher values (if the fractionation factor is underestimated), but this will not change the relative positions of samples on this W/R scale, provided temperature is in the $300^{\circ}-400^{\circ} \mathrm{C}$ range.

2. The fluid was either: (i) unmodified seawater $\left(\delta^{18} \mathrm{O}_{\text {fluid }}=0 \%\right)$, (ii) slightly ${ }^{18} \mathrm{O}$-depleted seawater $\left(\delta^{18} \mathrm{O}_{\text {fluid }}=-2 \%\right.$ ) because of pre- vious low-temperature interaction with basalts (Lawrence et al., $1975)$, or (iii) slightly ${ }^{18} \mathrm{O}$-enriched seawater $\left(\delta^{18} \mathrm{O}\right.$ fluid $=2 \%$ ) because of previous high-temperature hydrothermal interaction with hot rocks ( $>300^{\circ} \mathrm{C}$; Craig et al., 1980; Merlivat et al., 1987; Bowers and Taylor, 1985).

For such assumptions, the model, shown in Figure 8, systematically predicts depletions in ${ }^{18} \mathrm{O}$, which increase with the water/rock ratio for a given $\delta^{18} \mathrm{O}$ fluid. The calculated W/R ratios for the various values of the $\delta^{18} \mathrm{O}_{\text {fluid }}$ and the $\mathrm{D}$ (rock-fluid) can be determined from Figure 8 . The main result is that at least $\mathrm{W} / \mathrm{R} \approx 0.15$ (in atomic proportion $\approx 0.3$ in mass) is required to explain the less ${ }^{18} \mathrm{O}$-depleted samples $\left(\delta^{18} \mathrm{O} \approx 4.7 \%\right.$ : Samples $137-504 \mathrm{~B}-181 \mathrm{M}-1,7-9 \mathrm{~cm} ; 140-504 \mathrm{~B}-$ 208R-1, 56-61 cm; 140-504B-213R-1,79-83 cm for example) and $\mathrm{W} / \mathrm{R} \approx 0.5(\approx 1.0$ in mass $)$ to explain the most $\mathrm{O}$-depleted sample $\left(\delta^{18} \mathrm{O} \approx 2.7 \%\right.$ : $\left.140-504 \mathrm{~B}-205 \mathrm{R}-1,10-13 \mathrm{~cm}\right)$. Therefore, the range of the observed depletions in ${ }^{18} \mathrm{O}$ of Leg $137 / 140$ dolerites can be interpreted simply by variations in the W/R ratio, or in the ${ }^{18} \mathrm{O}$ composition of the fluid. This is because Taylor's model only yields coupled determinations for the W/R ratio and the $\delta^{18} \mathrm{O}$ fluid. This relationship is illustrated in Figure 9. It can be seen that ${ }^{18} \mathrm{O}$ depletion of dolerites to $\delta^{18} \mathrm{O}$ whole-rock $\approx 4.5 \%$ can be produced by any pair of $\mathrm{W} / \mathrm{R}$ and $\delta^{18} \mathrm{O}_{\text {fluid }}$ that defines the curve $\mathrm{A}$, and that the greater the W/R, the greater the $\delta^{18} \mathrm{O}_{\text {fluid. }}$. Curves $\mathrm{B}, \mathrm{C}$, and $\mathrm{D}$ are given for ${ }^{18} \mathrm{O}$ depletion of dolerites to $\delta^{18} \mathrm{O}_{\text {whole-rock }} \approx 4.0,3.5$, and 3.0 , respectively. This model shows that the minimum water/rock ratio required to produce the observed depletion in ${ }^{18} \mathrm{O}$ is about 0.15 in atomic proportion; below this value, exotic fluids $\left(\delta^{18} \mathrm{O}\right.$ fluid $\leq-4 \%$ ) are required.

\section{$\delta^{18} \mathrm{O}$ Profile in Hole 504B}

In Figure 10, we present a $\delta^{18} \mathrm{O}$ profile for Hole 504B; data previously published are included. As described by Alt et al. (1986, 1989), the upper part of the pillow-lava section is enriched in ${ }^{18} \mathrm{O}$ relative to the MORB values due to low-temperature hydrothermal interaction with seawater-derived fluids. There is a progressive decrease in ${ }^{18} \mathrm{O}$ with depth in this part of the hole. At the transition zone, between the pillow lavas and the dike complex, a sharp decrease in ${ }^{18} \mathrm{O}$ is seen, associated with a sharp decrease in the permeability of the rocks. Most of them have $\delta^{18} \mathrm{O}$ values lower than the MORB values. Deeper in the dike complex, all the rocks are systematically depleted in ${ }^{18} \mathrm{O}$ (see above). This character is explained by hightemperature hydrothermal interactions with seawater-derived fluids.

To integrate the $\delta^{18} \mathrm{O}$ profile of Hole 504B in the debate concerning the buffering of seawater ${ }^{18} \mathrm{O}$ composition by the alteration of the oceanic crust (Muehlenbachs and Clayton, 1976; Gregory and Taylor, 1981; Muehlenbachs, 1986), we have calculated an ${ }^{18} \mathrm{O}$ balance on the 196 measured values, corrected for the relative thicknesses of the units. The mean $(5.2 \% 0 \pm 0.07 \% 0 \mathrm{~s} / \mathrm{Vn})$ clearly shows that the upper part of the oceanic crust at Hole $504 \mathrm{~B}$ is depleted in ${ }^{18} \mathrm{O}$ by about $0.5 \%$ relative to the MORB values $(\approx 5.7 \% \circ \pm 0.2 \%$ ), thus indicating, in the case of Hole 504B, a net disequilibrium in the ${ }^{18} \mathrm{O}$ exchange between seawater and the oceanic crust in favor of enrichment in ${ }^{18} \mathrm{O}$ in the seawater. This unbalanced ${ }^{18} \mathrm{O}$ budget is in contrast with the buffering model, which is based on oceanic crust ${ }^{18} \mathrm{O}$ profiles where the enrichments in ${ }^{18} \mathrm{O}$ of the upper structural levels of the oceanic crust (basalts and dolerites mostly enriched in ${ }^{18} \mathrm{O}$ ) are balanced by the depletions in ${ }^{18} \mathrm{O}$ of the deeper levels (gabbros depleted in ${ }^{18} \mathrm{O}$ ). By analogy with other ${ }^{18} \mathrm{O}$ profiles, the Hole 504B deeper parts (to be drilled) may be assumed to be depleted in ${ }^{18} \mathrm{O}$ rather than enriched in ${ }^{18} \mathrm{O}$ due to high-temperature hydrothermal alteration. The ${ }^{18} \mathrm{O}$ disequilibrium for Hole $504 \mathrm{~B}$, therefore, is unlikely to be balanced by the ${ }^{18} \mathrm{O}$ contributions of the rocks of deeper levels. This character of Hole 504B may be due to a particularly strong expression of high-temperature hydrothermal interaction with seawater-derived fluids at shallow depths 


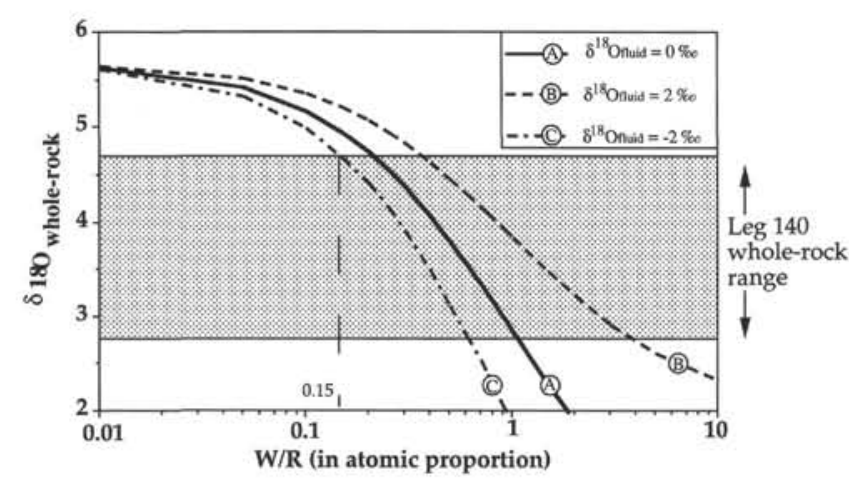

Figure $8 . \delta^{18} \mathrm{O}_{\text {whole-rock }}-\mathrm{W} / \mathrm{R}$ ratio diagram. Curves, calculated with Taylor's water-rock interaction model (1977), are given for different $\delta^{18} \mathrm{O}_{\text {fluid }}(=+2 \%$, $0 \%$, or $-2 \%$ ) and for fractionation factor (D(rock-fluid) $=0 \%$ ). W/R (in mass) $=\mathrm{W} / \mathrm{R}$ (in atomic proportion $) \times 2.1$.

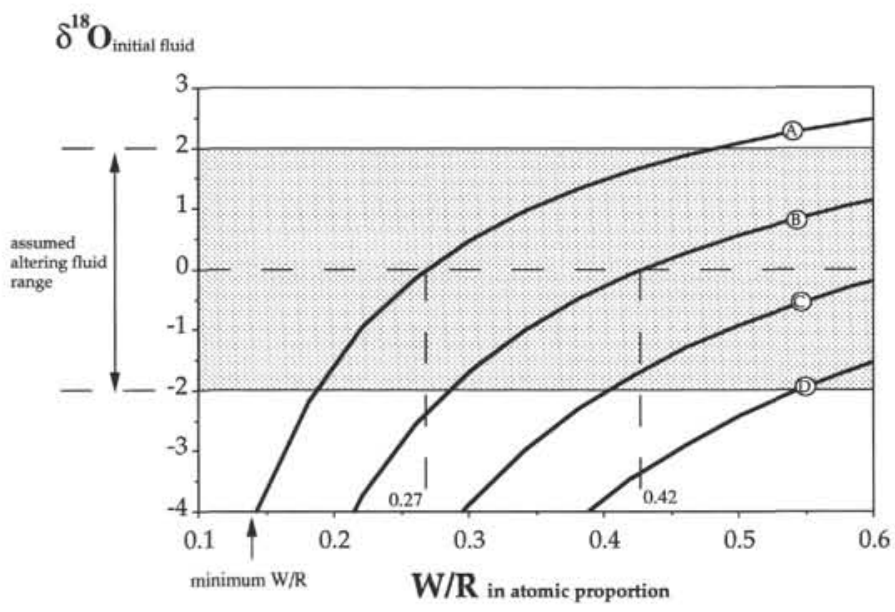

Figure 9. $8^{18} \mathrm{O}_{\text {initial fluid }}$-W/R ratio diagram. Curves A, B, C, and D, calculated with Taylor's water-rock interaction model (1977), are given for different $\delta^{18} \mathrm{O}_{\text {whole-rock }}(=+4 \%, 4.5 \%$, $4.0 \%$, and $3.5 \%$ for curves A, B, C, and D, respectively). The fractionation factor (D[rock-fluid]) was assumed to $0 \%$. This diagram shows that Taylor's water-rock interaction model yields coupled determinations for the $\delta^{18} \mathrm{O}_{\text {fluid }}$ and the W/R ratio parameters. If we assume that seawater was the initial fluid $\left(\delta^{18} \mathrm{O}_{\text {initial fluid }} \approx 0 \%\right)$ responsible for the observed depletion of the $\delta^{18} \mathrm{O}_{\text {whole-rock }}$ of the dolerites, we can deduce that depletion in ${ }^{18} \mathrm{O}$ to $\delta^{18} \mathrm{O}_{\text {whole-rock }}=+4$ requires water/rock ratio of 0.27 in atomic proportion $\left(\approx 0.54\right.$ in mass proportion). Lower $\delta^{18} \mathrm{O}_{\text {whole-rock }}$ values $(<4.5 \%)$ require higher water/rock ratio.

(i.e., in Layer 2), which is known to produce ${ }^{18} \mathrm{O}$-depleted rocks (Bowers and Taylor, 1985).

\section{ACKNOWLEDGMENTS}

We are grateful for having participated in Ocean Drilling Program Leg 140, which provided the samples from Hole 504B. C.L. expresses eternal thanks to Y. Lancelot and P. Pezard for their help during the 10 hours preceding the beginning of the leg. As part of the data used in this work was obtained on board during the cruise, we are thankful to all the cruise participants. Comments on this paper offered by Agnès Michel were very helpful. Reviews by Dr. J. Hoefs and an anonymous reviewer helped to improve the text. The English of this paper was greatly improved by S.R. Boyd and L. Dearmont. This study was supported by INSU Geosciences Marines (92/ATP/734).

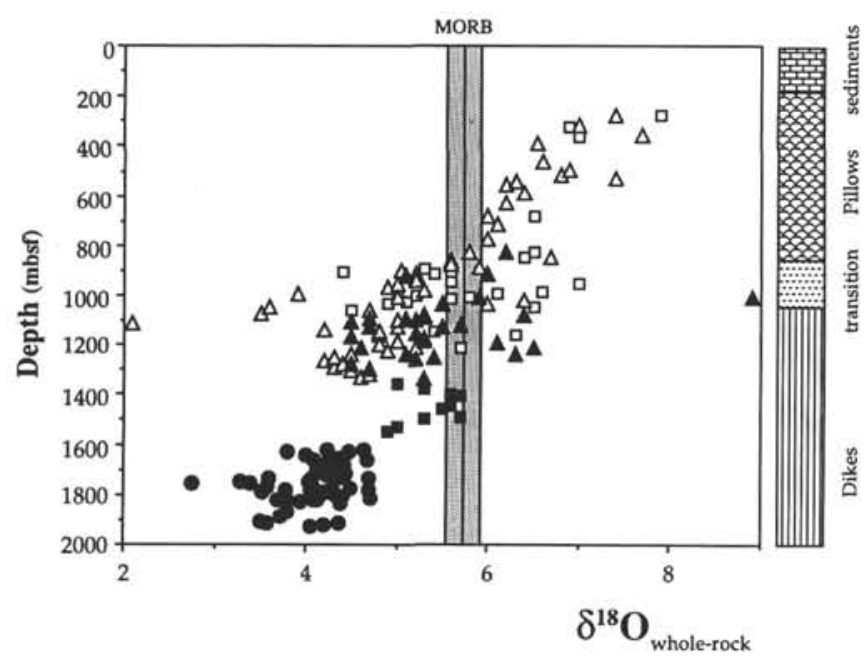

Figure $10 . \delta^{18} \mathrm{O}_{\text {whole-rock }}$-depth diagram. Data are from Altet al. (1985 and 1989), shown by solid triangles; from Barret and Friedrichsen (1982) and Friedrichsen (1985), both shown by open triangles; from Kawahata et al. (1985), shown by open squares; from Kusakabe et al. (1989), shown by solid squares; and from this work. The shaded area represents the ${ }^{18} \mathrm{O}$ value of fresh MORBs.

\section{REFERENCES*}

Agrinier, P., and Agrinier, B., in press. A propos de la connaissance de la profondeur à laquelle vos échantillons sont collectés dans les forages. Comptes Rendus de l'Académie des Sciences.

Alt, J.C., Anderson, T.F., Bonnell, L., and Muehlenbachs, K., 1989. Mineralogy, chemistry, and stable isotopic compositions of hydrothermally altered sheeted dikes: ODP Hole 504B, Leg 111. In Becker, K., Sakai, H., et al., Proc. ODP, Sci. Results, 111: College Station, TX (Ocean Drilling Program), 27-40.

Alt, J.C., Laverne, C., and Muehlenbachs, K., 1985. Alteration of the upper oceanic crust: mineralogy and processes in Deep Sea Drilling Project Hole 504B, Leg 83. In Anderson, R.N., Honnorez, J., Becker, K., et al., Init. Repts. DSDP, 83: Washington (U.S. Govt. Printing Office), 217-247.

Alt, J.C., Muehlenbachs, K., and Honnorez, J., 1986. An oxygen isotopic profile through the upper kilometer of the oceanic crust, DSDP Hole 504B. Earth Planet. Sci. Lett., 80:217-229,

Barrett, T.J., and Friedrichsen, H., 1982. Strontium and oxygen isotopic composition of some basalts from Deep Sea Drilling Project Hole 504B, Costa Rica Rift, Legs 69, 70. Earth Planet. Sci. Lett., 60:27-38.

Böhlke, J.K., Alt, J.C., and Muehlenbachs, K., 1984. Oxygen isotope-water relations in altered deep-sea basalts: low temperature mineralogical controls. Can. J. Earth Sci., 21:67-77.

Böhlke, J.K., Honnorez, J., Honnorez-Guerstein, B.M., Muehlenbachs, K., and Petersen, N., 1981. Heterogeneous alteration of the upper oceanic crust: correlation of rock chemistry, magnetic properties, and $\mathrm{O}$ isotope ratios with alteration pattern in basalts from Site 396B, DSDP. J. Geophys. Res., 86:7935-7950.

Bottinga, Y., and Javoy, M., 1975. Oxygen isotope partitioning among the minerals in igneous and metamorphic rocks. Rev. Geophys. Space Phys., 20:250-265.

Bowers, T.S., and Taylor, H.P., Jr., 1985. An integrated chemical and stable isotope model of the origin of midocean ridge hot spring systems. $J$. Geophys. Res., 90:12583-12606.

Clayton, R.N., and Mayeda, T.K., 1963. The use of bromine pentafluoride in the extraction of oxygen from oxides and silicates for isotopic analysis. Geochim. Cosmochim. Acta, 27:43-52.

Coleman, M.L., Shepherd, T.J., Durham, J.J., Rouse, J.E., and Moore, G.R., 1982. Reduction of water with zinc for hydrogen isotope analysis. Anal. Chem., 54:993-995.

-Abbreviations for names of organizations and publication titles in ODP reference lists follow the style given in Chemical Abstracts Service Source Index (published by American Chemical Society). 
Craig. H., Welhan, J.A., Kim, K., Poreda, R., and Lupton, J.E., 1980. Geochemical studies of the $21^{\circ} \mathrm{N}$ EPR hydrothermal fluids. Eos, 61:992.

Dick. H.J.B., Erzinger, J., Stokking, L.B., et al., 1992. Proc. ODP, Init. Repts., 140: College Station, TX (Ocean Drilling Program).

Francheteau, J., Armijo. R., Cheminée, J.L., Hekinian, R., Lonsdale, P., and Blum, N., 1992. Dike complex of the East Pacific Rise exposed in the walls of Hess Deep and the structure of the upper oceanic crust. Earth Planet. Sci. Lett., 111:109-121.

Friedrichsen, H., 1985. Strontium, oxygen, and hydrogen isotope studies on primary and secondary minerals in basalts from the Costa Rica Rift, Deep Sea Drilling Project Hole 504B, Leg 83. In Anderson, R.N., Honnorez, J., Becker, K., et al., Init. Repts. DSDP, 83: Washington (U.S. Govt. Printing Office), 289-295.

Graham, C.M., Harmon, R.S., and Sheppard, S.M.F., 1984. Experimental hydrogen isotope studies: hydrogen isotope exchange between amphibole and water. Am. Mineral., 69:128-138.

Graham, C.M., Viglino, J.A., and Harmon, R.S., 1987. An experimental study of hydrogen isotope exchange between aluminous chlorite and water. $\mathrm{Am}$. Mineral., 72:566-579.

Gregory, R.T., and Taylor, H.P., Jr., 1981. An oxygen isotope profile in a section of cretaceous oceanic crust, Samail ophiolite, Oman: evidence for $\delta^{18} \mathrm{O}$ buffering of the oceans by deep ( $>5 \mathrm{~km}$ ) seawater-hydrothermal circulation at mid-ocean ridges. J. Geophys. Res., 86:2737-2755.

Honnorez, J., Laverne, C., Hubberten, H.-W., Emmermann, R., and Muehlenbachs, K., 1983. Alteration processes in Layer 2 basalts from Deep Sea Drilling Project Hole 504B, Costa Rica Rift. In Cann, J.R., Langseth, M.G., Honnorez, J., Von Herzen, R.P., White, S.M., et al., Init. Repts. DSDP. 69: Washington (U.S. Govt. Printing Office), 509-546.

Javoy, M., and Fouillac, A.M., 1979. Stable isotope ratios in Deep Sea Drilling Project Leg 51 basalts. In Donnelly, T., Francheteau, J., Bryan, W., Robinson, P., Flower, M., Salisbury, M., et al., Init. Repts. DSDP, 51, 52, 53 (Pt. 2): Washington (U.S. Govt. Printing Office), 1153-1157.

Kawahata, H., Kusakabe, M., and Kikuchi, Y., 1987. Strontium, oxygen and hydrogen isotope geochemistry of hydrothermally altered and weathered rocks in DSDP Hole 504B, Costa Rica Rift. Earth Planet. Sci. Lett., 85:343-355.

Kusakabe, M., Shibata, T., Yamamoto, M., Mayeda, S., Kagami, H., Honma, H., Masuda, H., and Sakai, H., 1989. Petrology and isotope characteristics $(\mathrm{H}, \mathrm{O}, \mathrm{S}, \mathrm{Sr}$, and Nd) of basalts from Ocean Drilling Program Hole 504B, Leg 111, Costa Rica Rift. In Becker, K., Sakai, H., et al., Proc. ODP, Sci. Results, 111: College Station, TX (Ocean Drilling Program), 47-60.
Kyser, T.K., and O'Neil, J.R., 1984. Hydrogen isotope systematics of submarine basalts. Geochim. Cosmochim. Acta, 48:2123-2133.

Laverne, C.. Honnorez, J., and Alt, J.C., 1989. Transition entre l'altération à basse température et le métamorphisme hydrothermal de la croûte océanique: étude pétrographique et géochimique du puits 504B, Est-Pacifique. Bull. Soc. Geol. Fr., 8:327-337.

Lawrence, J.R., Gieskes, J.M., and Broecker, W.S., 1975. Oxygen isotope and cation composition of DSDP pore water and the alteration of layer II basalts. Earth Planet. Sci. Lett., 27:1-10.

Merlivat, L., Pineau, F., and Javoy, M., 1987. Hydrothermal vent waters at $13^{\circ} \mathrm{N}$ on the East Pacific Rise: isotopic composition and gas concentration. Earth Planet. Sci. Lett., 84:100-108.

Muehlenbachs, K., 1986. Alteration of the ocean crust and ${ }^{18} \mathrm{O}$ history of seawater. In Valley, J.W., Taylor, H.P., Jr., and O'Neil, J.R. (Eds.), Stable Isotopes in High Temperature Geological Processes. Mineral. Soc. Am., Rev. Mineral., 16:425-444.

Muehlenbachs, K., and Clayton, R.N., 1976. Oxygen isotope composition of the oceanic crust and its bearing on seawater. J. Geophys. Res., 81:43654369 .

, 1972. Oxygen isotope studies of fresh and weathered submarine basalts. Can. J. Earth Sci., 9:172-184.

Nicolas, A., 1991. Structures of Ophiolites and Dynamics of Oceanic Lithosphere: Dordrecht (Kluwer Academic Publ).

O'Neil, J.R., and Taylor, H.P., Jr., 1967. The oxygen isotope and cation exchange chemistry of feldspars. Am. Mineral., 52:1414-1437.

Schütze, H., 1984. Isotopengeochemische Modellrechnungen zur Entwicklung der kontinentalen Kruste auf der Basis eines Isotopenindex von Silicaten. Geophys. Geol. Veroff. KMU Leipzig Bd. III, 1:25-92.

Suzuoki, T., and Epstein, S., 1976. Hydrogen isotope fractionation between $\mathrm{OH}$-bearing minerals and water. Geochim. Cosmochim. Acta, 40:12291240.

Taylor, H.P., Jr., 1977. Water/rock interaction and the origin of $\mathrm{H}_{2} \mathrm{O}$ in granitic batholiths. J. Geol. Soc. London, 133:509-558.

Wenner, D.B., and Taylor, H.P., Jr., 1971. Temperatures of serpentinization of ultramafic rocks based on ${ }^{16} \mathrm{O} /{ }^{18} \mathrm{O}$ fractionation between coexisting serpentine and magnetite. Contrib. Mineral. Petrol., 32:165-185.

Date of initial receipt: 20 May 1993

Date of acceptance: 13 January 1994

Ms 137/140SR-016 